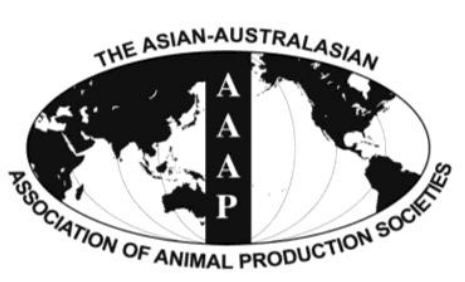

Open Access

Asian Australas. J. Anim. Sci.

Vol. 27, No. 2 : 187-193 February 2014

http://dx.doi.org/10.5713/ajas.2013.13395

www.ajas.info

pISSN 1011-2367 elSSN 1976-5517

\title{
Effects of Combining Feed Grade Urea and a Slow-release Urea Product on Characteristics of Digestion, Microbial Protein Synthesis and Digestible Energy in Steers Fed Diets with Different Starch:ADF Ratios
}

\author{
M. A. López-Soto, C. R. Rivera-Méndez, J. A. Aguilar-Hernández, A. Barreras, J. F. Calderón-Cortés, \\ A. Plascencia*, H. Dávila-Ramos ${ }^{1}$, A. Estrada-Angulo ${ }^{1}$, and Y. S. Valdes-García ${ }^{2}$ \\ Research Institute of Veterinary Sciences, University Autonomous of Baja California, México
}

\begin{abstract}
As a result of the cost of grains, the replacement of grains by co-products (i.e. DDGS) in feedlot diets is a common practice. This change produces diets that contain a lower amount of starch and greater amount of fibre. Hypothetically, combining feed grade urea (U) with slow release urea (Optigen) in this type of diet should elicit a better synchrony between starch (high-rate of digestion) and fibre (low-rate of digestion) promoting a better microbial protein synthesis and ruminal digestion with increasing the digestible energy of the diet. Four cannulated Holstein steers $(213 \pm 4 \mathrm{~kg})$ were used in a $4 \times 4$ Latin square design to examine the combination of Optigen and $\mathrm{U}$ in a finishing diet containing different starch:acid detergent fibre ratios (S:F) on the characteristics of digestive function. Three S:F ratios (3.0, 4.5, and 6.0) were tested using a combination of U $(0.80 \%)$ and Optigen (1.0\%). Additionally, a treatment of $4.5 \mathrm{~S}: \mathrm{F}$ ratio with urea $(0.80 \%$ in ration) as the sole source of non-protein nitrogen was used to compare the effect of urea combination at same S:F ratio. The S:F ratio of the diet was manipulated by replacing the corn grain by dried distillers grain with solubles and roughage. Urea combination did not affect ruminal $\mathrm{pH}$. The S:F ratio did not affect ruminal $\mathrm{pH}$ at 0 and $2 \mathrm{~h}$ post-feeding but, at 4 and $6 \mathrm{~h}$, the ruminal $\mathrm{pH}$ decreased as the $\mathrm{S}: \mathrm{F}$ ratio increased (linear, $\mathrm{p}<0.05$ ). Ruminal digestion of OM, starch and feed $\mathrm{N}$ were not affected by urea combination or $\mathrm{S}: \mathrm{F}$ ratio. The urea combination did not affect ADF ruminal digestion. ADF ruminal digestion decreased linearly $(\mathrm{p}=0.02)$ as the $\mathrm{S}: \mathrm{F}$ ratio increased. Compared to the urea treatment $(\mathrm{p}<0.05)$ and within the urea combination treatment (quadratic, $\mathrm{p}<0.01$ ), the flow of microbial nitrogen $(\mathrm{MN})$ to the small intestine and ruminal microbial efficiency were greater for the urea combination at a $S: F$ ratio of 4.5. Irrespective of the $S: F$ ratio, the urea combination improved $(2.8 \%, p=0.02)$ postruminal $\mathrm{N}$ digestion. As S:F ratio increased, OM digestion increased, but ADF total tract digestion decreased. The combination of urea at $4.5 \mathrm{~S}: \mathrm{F}$ improved $(2 \%, \mathrm{p}=0.04)$ the digestible energy $(\mathrm{DE})$ more than expected. Combining urea and Optigen resulted in positive effects on the MN flow and DE of the diet, but apparently these advantages are observed only when there is a certain proportion of starch:ADF in the diet. (Key Words: Slow-release Urea, Finishing Diets, Steers, Digestion, Microbial Nitrogen)
\end{abstract}

\section{INTRODUCTION}

It is well known that, ruminal microbial protein synthesis (MPS) is the most important process in ruminant nitrogen $(\mathrm{N})$ metabolism, since MPS not only contributes more than $50 \%$ of the amino acids absorbed in the small

\footnotetext{
* Corresponding Author: Alejandro Plascencia. Tel: +52-686-563 6906 (111), Fax: +52-686-5636907, E-mail: aplas_99@yahoo.com

${ }^{1}$ Veterinary School, University Autonomous of Sinaloa, México.

${ }^{2}$ Academic Unit of Veterinary and Animal Science, University Autonomous of Nayarit, México.

Submitted Jul. 7, 2013; Accepted Aug. 8, 2013; Revised Sept. 1, 2013
}

intestine, but also has an amino acid composition similar to that of the proteins required for meat production (Zinn and Owens, 1983; NRC, 1985; Seo et al., 2013). The N retention in the rumen is mainly mediated by the rate of degradation of $\mathrm{N}$ compounds and carbohydrates and by the energy available for the process of protein synthesis. It has been observed that in high-grain diets (ratio of starch vs. acid detergent fibre greater than 5.5 to 1) urea can be supplemented at $50 \%$ higher than recommended with positive effects on growth performance or in dietary energy utilization (Milton et al., 1997; Zinn et al., 2003). The latter can be partially explained by the possible synchrony of

Copyright $@ 2014$ by Asian-Australasian Journal of Animal Sciences This is an open-access article distributed under the terms of the Creative Commons Attribution Non-Commercial License (http://creativecommons.org/licenses/by-nc/3.0/), which permits unrestricted non-commercial use, distribution, and reproduction in any medium, provided the original work is properly cited. 
ruminal degradation rates between urea and starch. Currently, as a result of the cost of corn grain, the replacement of corn grain by dried distillers grain with solubles (DDGS) in feedlot diets is a common practice (Klopfenstein et al., 2008). Although the energy value of DDGS is similar to steam flaked corn (NRC, 1996), DDGS are lower in starch content $(<6 \%)$ and higher in their content $(>30 \%)$ of digestible fibre (Rosentrater, 2012; Carrasco et al., 2013). Therefore, depending on the replacement level, the fibre content in finishing diets can be increased up to two-fold (from $8 \%$ to $15 \%$ of total acid detergent fibre $[\mathrm{ADF}]$ ) and the total starch content can be decreased by $20 \%$ (from $50 \%$ to $40 \%$ ). Hypothetically, combining feed grade urea with slow-release urea in finishing diets should promote the synchrony between starch (high-rate of digestion) and fibre (low-rate of digestion), promoting better microbial protein synthesis and increases in ruminal digestion and the digestible energy of the diet. The beneficial effects of the supplementation of slow-release urea has been extensively studied in cattle that were fed a high-forage diets, i.e. rations for dairy and growing cattle (Inostroza et al., 2010; Alvarez et al., 2011); however, no research has examined the role of the starch:fibre ratio of the finishing diets on the effects of the combination of both sources of urea. Therefore, the purpose of this study was to evaluate the effects of combining feed grade urea and a slow-release urea product (OPT) on the characteristics of digestion, microbial protein synthesis and digestible energy in steers fed diets with different starch:ADF ratios.

\section{MATERIALS AND METHODS}

The trial was conducted at the Ruminant Metabolism Experimental Unit of the Instituto de Investigaciones en Ciencias Veterinarias of the Universidad Autónoma de Baja California located $10 \mathrm{~km}$ south of Mexicali City in northwestern México (32 $40^{\prime} 7^{\prime \prime} \mathrm{N}$ and $\left.115^{\circ} 28^{\prime} 6^{\prime \prime} \mathrm{W}\right)$. The area is about $10 \mathrm{~m}$ above sea level, and has Sonoran desert conditions (BWh classification according to Köppen). All animal management procedures were conducted within the guidelines of locally-approved techniques for animal use and care (NOM-051-ZOO-1995: humanitarian care of animals during mobilization of animals; NOM-062-ZOO1995: technical specifications for the care and use of laboratory animals. Livestock farms, farms, centres of production, reproduction and breeding, zoos and exhibition hall, must meet the basic principles of animal welfare; NOM-024-ZOO-1995: animal health stipulations and characteristics during transportation of animals. These regulations are in accordance with the principles and specific guidelines presented in the Guidelines for the Care and Use of Agricultural Animals in Agricultural Research and Teaching (FASS, 2010).

\section{Animals, diets and sampling}

Four Holstein steers $(213 \pm 4 \mathrm{~kg})$ with ruminal and duodenal cannulas (Zinn and Plascencia, 1993) were used in a $4 \times 4$ Latin square design to examine the effect of the combination of Optigen (a polymer-coated urea; Optigen, Alltech Mexico, Guadalajara, Jalisco) and U in a finishing diet containing different starch:acid detergent fibre ratios ( $\mathrm{S}: \mathrm{F})$ on the characteristics of digestion, microbial protein synthesis and digestible energy of diet. Three S:F ratios (3.0, 4.5, and 6.0) were tested using a combination of $U(0.80 \%)$ and Optigen $(1.0 \%)$. Additionally, a treatment of $4 \mathrm{~S}: \mathrm{F}$ ratio with urea $(0.80 \%$ in ration) as sole source of NPN was used to compare the effect of urea combination at same $S: F$ ratio. For the above, four dietary treatments were compared:

- Diet formulated to supply $2.14 \mathrm{Mcal} / \mathrm{kg}$ of $\mathrm{NE}_{\mathrm{m}}$ with a $\mathrm{S}: \mathrm{F}$ ratio of 4.5 , containing $0.80 \%$ conventional urea as the sole source of NPN (U-4.5)

- Diet formulated to supply $2.14 \mathrm{Mcal} / \mathrm{kg}$ of $\mathrm{NE}_{\mathrm{m}}$ with a S:F ratio of 6.0 , containing $0.80 \%$ conventional urea plus $1.00 \%$ OPT (OPT-6)

- Diet formulated to supply $2.07 \mathrm{Mcal} / \mathrm{kg}$ of $\mathrm{NE}_{\mathrm{m}}$ with a $\mathrm{S}: \mathrm{F}$ ratio of 4.5 , containing $0.80 \%$ conventional urea plus $1.00 \%$ OPT (OPT-4.5)

- Diet formulated to supply $2.00 \mathrm{Mcal} / \mathrm{kg}$ of $\mathrm{NE}_{\mathrm{m}}$ with a $\mathrm{S}: \mathrm{F}$ ratio of 3.0 , containing $0.80 \%$ conventional urea plus $1.00 \%$ of OPT (OPT-3)

The $S: F$ ratio in the diet was manipulated by replacing the steam-flaked corn grain by dried distillers grain with solubles (DDGS) and forage (sudangrass hay and wheat straw) to reach $\mathrm{S}: \mathrm{F}$ ratios of $3.0,4.5$, or 6.0 (Table 1). Chromic oxide (used as a source of chromium to estimate nutrient flow and coefficient of digestion) was added to the diets (3.5 g/kg of diet on an air dry basis) and it was premixed with minor ingredients (urea and mineral supplement composed of limestone and trace mineral salts) before incorporation into complete mixed diets. All steers received ad libitum access to the control diet (U-4.5) for 14 days before initiation of the trial. To avoid refusals once the experiment started, dry matter intake was restricted to 4.55 $\mathrm{kg} / \mathrm{d}$ (90\% of observed ad libitum intake of steers during the 14-d preliminary period). The slow-release urea product was hand-weighed using a precision balance (Ohaus, mod AS612, Pine Brook, NJ), and was added (top-dressed) in equal proportions to the diet at time of feeding. Diets were fed in two equal portions at 0800 and $2000 \mathrm{~h}$ daily. Animals were housed in individual pens $\left(3.9 \mathrm{~m}^{2}\right)$ in an indoor facility with a concrete floor covered by a neoprene carpet, automatic waterers and individual feed bunks. Experimental periods consisted of a 17-d diet adjustment period followed 
Table 1. Ingredients and composition of experimental diets

\begin{tabular}{|c|c|c|c|c|}
\hline \multirow{2}{*}{ Item } & \multicolumn{4}{|c|}{ Treatments } \\
\hline & U-4.5 & OPT-6.0 & OPT-4.5 & OPT-3.0 \\
\hline \multicolumn{5}{|c|}{ Ingredient composition (\% DMB) } \\
\hline Steam flaked corn & 58.00 & 68.00 & 60.00 & 55.00 \\
\hline DDGS & 15.00 & 4.00 & 6.50 & 7.00 \\
\hline Sudangrass hay & 6.00 & 6.00 & 10.00 & 12.00 \\
\hline Wheat straw & 4.00 & 4.00 & 5.50 & 8.00 \\
\hline Urea & 0.80 & 0.80 & 0.80 & 0.80 \\
\hline Optigen $1200^{1}$ & - & 1.00 & 1.00 & 1.00 \\
\hline Cane molasses & 8.00 & 8.00 & 8.00 & 8.00 \\
\hline Bakery waste & 3.50 & 3.50 & 3.50 & 3.50 \\
\hline Yellow grease & 2.00 & 2.00 & 2.00 & 2.00 \\
\hline Trace mineral salt ${ }^{2}$ & 0.40 & 0.40 & 0.40 & 0.40 \\
\hline Limestone & 1.80 & 1.80 & 1.80 & 1.80 \\
\hline Chromic oxide & 0.35 & 0.35 & 0.35 & 0.35 \\
\hline \multicolumn{5}{|c|}{ NE concentration ${ }^{3}$ (Mcal/kg of DM basis) } \\
\hline $\mathrm{EN}_{\mathrm{m}}(\mathrm{Mcal} / \mathrm{kg})$ & 2.14 & 2.14 & 2.07 & 2.00 \\
\hline $\mathrm{EN}_{\mathrm{g}}(\mathrm{Mcal} / \mathrm{kg})$ & 1.48 & 1.48 & 1.41 & 1.34 \\
\hline \multicolumn{5}{|c|}{ Nutrient composition (\% of DM $)^{4}$} \\
\hline Crude protein & 12.48 & 13.50 & 13.70 & 13.53 \\
\hline Starch & 42.92 & 48.20 & 44.90 & 39.40 \\
\hline $\mathrm{ADF}$ & 9.63 & 8.03 & 10.10 & 13.27 \\
\hline Calcium & 0.73 & 0.78 & 0.80 & 0.73 \\
\hline Phosphorus & 0.43 & 0.31 & 0.33 & 0.33 \\
\hline
\end{tabular}

${ }^{1}$ Optigen-1200. Alltech de México, Guadalajara Jalisco.

${ }^{2}$ Trace mineral salt contained: $\mathrm{CoSO}_{4}, 0.068 \%$; $\mathrm{CuSO}_{4}, 1.04 \% ; \mathrm{FeSO}_{4}, 3.57 \% ; \mathrm{ZnO}, 1.24 \% ; \mathrm{MnSO}_{4}, 1.07 \% ; \mathrm{KI}, 0.052 \% ; \mathrm{NaCl}, 92.96 \%$.

${ }^{3}$ Based on tabular net energy (NE) values for individual feed ingredients (NRC, 2000) with the exception of supplemental fat, which was assigned $\mathrm{NE}_{\mathrm{m}}$ and $\mathrm{NE}_{\mathrm{g}}$ values of 6.03 and 4.79, respectively (Zinn, 1988).

${ }^{4}$ Dietary composition was determined by analyzing subsamples collected and composited throughout the experiment. Accuracy was ensured by adequate replication with acceptance of mean values that were within $5 \%$ of each other.

by a 4-d collection period. During the collection period, duodenal and faecal samples were taken from all steers, twice daily as follows: $\mathrm{d}$ 1, 0750 and $1350 \mathrm{~h}$; d 2, 0900 and $1500 \mathrm{~h}$; d 3, 1050 and $1650 \mathrm{~h}$; and d 4, 1200 and $1800 \mathrm{~h}$. Individual samples consisted of approximately $500 \mathrm{~mL}$ of duodenal chyme and $200 \mathrm{~g}$ (wet basis) of faecal material. Samples from each steer and within each collection period were prepared for analysis. During the final day of each collection period, a ruminal sample $(\sim 500 \mathrm{~mL})$ was obtained from each steer at $0,2,4$, and $6 \mathrm{~h}$ after feeding via the ruminal cannula. Ruminal fluid was taken from the ruminal ventral sac by vacuum pump (Cole Parmer Instrument, Vernon Hill, IL) using a Tygon tube (i.d. 0.95 cm; USP Lima, Ohio), and $\mathrm{pH}$ of fresh samples was determined (Orion 261S, Fisher Scientific, Pittsburgh, PA.). Upon completion of the trial, ruminal fluid was obtained from all steers and composited for isolation of ruminal bacteria via differential centrifugation (Bergen et al., 1968). The microbial isolate served as the purine: $\mathrm{N}$ reference for the estimation of microbial $\mathrm{N}$ contribution to chyme entering the small intestine (Zinn and Owens, 1986).

\section{Sample analysis and calculations}

Feed, duodenal and faecal samples were subjected to the following analysis: DM (oven drying at $105^{\circ} \mathrm{C}$ until no further weight loss; method 930.15; AOAC, 2000); ash (method 942.05; AOAC, 2000), Kjeldahl N (method 984.13; AOAC, 2000); ADF (Van Soest et al., 1991); chromic oxide (Hill and Anderson, 1958); and starch (Zinn, 1990). In addition, gross energy (GE, using the adiabatic bomb model 1271; Parr Instrument Co., Moline, IL. USA) was determined for feed and faecal samples. Ammonia $\mathrm{N}$ (method 941.04; AOAC, 2000) and purines (Zinn and Owens, 1986) were determined in duodenal samples. Ether extract (method 920.39; AOAC, 2000), calcium (method 927.02; AOAC, 2000) and phosphorus (method 964.06; AOAC, 2000) were determined in feed samples.

Microbial organic matter (MOM) and microbial nitrogen (MN) leaving the abomasum were calculated using purines as a microbial marker (Zinn and Owens, 1986). Organic matter fermented in the rumen (OMF) was considered equal to the $\mathrm{OM}$ intake minus the difference between the amount of total OM reaching the duodenum and the MOM reaching the duodenum. Feed $\mathrm{N}$ escaping to 
the small intestine was considered equal to the total $\mathrm{N}$ leaving the abomasum minus ammonia- $\mathrm{N}$ and $\mathrm{MN}$ and, thus, includes any endogenous contributions.

\section{Statistical design and analysis}

The effects of the treatments on the characteristics of digestion in the cattle were analysed as a $4 \times 4$ Latin square design using the GLM procedure (SAS Inst. Inc., Cary, NC). The statistical model for the trial was as follows:

$$
\mathrm{Y}_{\mathrm{ijk}}=\mu+\mathrm{S}_{\mathrm{i}}+\mathrm{P}_{\mathrm{j}}+\mathrm{T}_{\mathrm{k}}+\mathrm{E}_{\mathrm{ijk}},
$$

Where, $\mathrm{Y}_{i j k}$ is the response variable, $\mu$ is the common experimental effect, $\mathrm{S}_{i}$ is the steer effect, $\mathrm{P}_{j}$ is the period effect, $\mathrm{T}_{k}$ is the treatment effect and $\mathrm{E}_{i j k}$ is the residual error. The response curves of the S:F ratio in OPT treatments were analysed with orthogonal polynomials. In addition, the urea combination (urea vs OPT) at same S:F ratio (4.5) was compared using the Student's t-test. The analysis was carried out using SAS (SAS Inst., Inc., Cary, NC; Version 9.1). The ruminal $\mathrm{pH}$ values, which were recorded at $0,2,4$, and $6 \mathrm{~h}$ post-feeding, were analysed with a linear mixed model for repeated measures in a Latin square design according to SAS (SAS Inst., Inc., Cary, NC; Version 9.1), with evaluation of the covariance structures: A, CS, AR (1), and the animal as random components.

\section{RESULTS AND DISCUSSIONS}

The ratios of starch:ADF determined in the laboratory reached at least $98 \%$ of the planned for each treatment (Table 1). The effects of treatment on ruminal $\mathrm{pH}$ are shown in Table 2. The ruminal $\mathrm{pH}$ observed for each treatment in the present study was slightly greater $(3.7 \%)$ than predicted based on the diet formulation (NRC, 1996, Level 1). This may be because of the incorporation of $1.80 \%$ limestone in the diet (Table 1), which has a high ruminal buffering capacity (Russell et al., 1980; Haaland et al., 1982). Ruminal $\mathrm{pH}$ was not affected by urea combination. The S:F ratio did not affect ruminal $\mathrm{pH}$ at 0 and $2 \mathrm{~h}$ post-feeding but, at 4 and $6 \mathrm{~h}$ post-feeding, the ruminal $\mathrm{pH}$ decreased as the $\mathrm{S}: \mathrm{F}$ ratio increased (linear, $\mathrm{p}<0.05$ ). As consequence of the rapid ruminal fermentation of starch, diets that contain increasing amounts of starch (grains) tend to promote a lower ruminal $\mathrm{pH}$ than those that contain lower quantities of starch (Huntington, 1997). In this sense, the S:F ratio of 6.0 contained $6.8 \%$ and $8.2 \%$ more starch than S:F ratios 4.5 and 3.0, respectively. At equal $\mathrm{S}: \mathrm{F}$ ratios, the ruminal $\mathrm{pH}$ was very similar $(\mathrm{p}=0.98)$ between the urea and OPT treatments, averaging 6.26 vs 6.22 for U-4.5 and OPT-4.5, respectively. This indicates that, although U-4.5 contained $3.3 \%$ more energy than OPT-4.5 (2.14 vs 2.07 Mcal $\mathrm{EN}_{\mathrm{m}} / \mathrm{kg}$ ), the $\mathrm{S}: \mathrm{F}$ is the most important factor, rather than the energy level per se, that impacts the ruminal $\mathrm{pH}$.

Treatment effects on the characteristics of ruminal and total tract digestion are summarized in Table 3. Urea combination did not modify ruminal digestion of OM, starch, ADF, and feed N. The S:F ratio did not affect the ruminal digestion of $\mathrm{OM}$, starch and feed $\mathrm{N}$, however, ruminal ADF digestion decreased linearly $(p=0.02)$ as the $\mathrm{S}: \mathrm{F}$ ratio increased. It has been observed that the depression in fibre digestion is largely a function of ruminal anion concentration (Peters et al., 1992). Russell and Wilson (1996) observed that fibre digestion decreases because cellulolytic bacteria cannot adequately control their intracellular anion gradient as $\mathrm{pH}$ declines. Grant and Weidner (1992) further verified this concept in vitro by fermenting various forages in cultures of ruminal fluid wherein $\mathrm{pH}$ was controlled experimentally by means of citrate buffers. They observed that both the lag phase and the rate of fibre digestion were sensitive to sustained culture $\mathrm{pH}$ below 6.2. The ruminal $\mathrm{pH}$ with the OPT-6 treatment was consistently maintained below 6.0 , while in the rest of the treatments ruminal $\mathrm{pH}$ remained above 6.2 (Table 2).

The flow of microbial $\mathrm{N}$ to the small intestine (quadratic effect, $\mathrm{p}<0.01$ ) and ruminal microbial efficiency (flow of microbial $\mathrm{N}$ to the small intestine as a proportion of fermented OM; quadratic effect, $\mathrm{p}=0.03$ ) were greater than the 4.5 S:F ratio within OPT treatments. In the same manner, compared to the control diet, at an equal S:F ratio (4.5), the

Table 2. Effects of treatments on ruminal $\mathrm{pH}$ taken at $0,2,4$, and $6 \mathrm{~h}$ post-feeding

\begin{tabular}{|c|c|c|c|c|c|c|c|c|}
\hline \multirow{2}{*}{ Item } & \multicolumn{4}{|c|}{ Treatments $^{1}$} & \multirow{2}{*}{ EEM } & \multirow{2}{*}{ U-4.5 vs OPT- 4.5} & \multicolumn{2}{|c|}{ S:F ratio } \\
\hline & $\mathrm{U}-4.5$ & OPT-6 & OPT-4.5 & OPT-3 & & & Linear & Quadratic \\
\hline \multicolumn{9}{|c|}{$\overline{\text { Ruminal } \mathrm{pH}}$} \\
\hline $0 \mathrm{~h}$ & 6.60 & 6.47 & 6.56 & 6.76 & 0.12 & 0.19 & 0.06 & 0.19 \\
\hline $2 \mathrm{~h}$ & 5.82 & 5.84 & 5.89 & 6.05 & 0.07 & 0.67 & 0.09 & 0.63 \\
\hline $4 \mathrm{~h}$ & 6.20 & 5.80 & 6.11 & 6.15 & 0.09 & 0.48 & 0.04 & 0.32 \\
\hline $6 \mathrm{~h}$ & 6.42 & 6.06 & 6.41 & 6.51 & 0.09 & 0.98 & 0.02 & 0.31 \\
\hline
\end{tabular}

${ }^{1} \mathrm{U}-4.5$ = Diet formulated to supply $2.14 \mathrm{Mcal} / \mathrm{kg}$ of $\mathrm{NE}_{\mathrm{m}}$ with a ratio of starch:FDA of 4.5 , containing $0.80 \%$ of conventional urea as the sole source of NNP; OPT-6 = Diet formulated to supply $2.14 \mathrm{Mcal} / \mathrm{kg}$ of $\mathrm{NE}_{\mathrm{m}}$ with a ratio of starch:FDA of 6.0 , containing $0.80 \%$ of conventional urea plus $1.00 \%$ of Optigen; OPT-4.5 = Diet formulated to supply $2.07 \mathrm{Mcal} / \mathrm{kg}$ of $\mathrm{NE}_{\mathrm{m}}$ with a ratio of starch:FDA of 4.5 , containing $0.80 \%$ of conventional urea plus $1.00 \%$ of Optigen, and OPT-3 = Diet formulated to supply $2.00 \mathrm{Mcal} / \mathrm{kg}$ of $\mathrm{NE}_{\mathrm{m}}$ with a ratio of starch:FDA of 3.0, containing $0.80 \%$ of conventional urea plus $1.00 \%$ of Optigen (OPT-3). 
Table 3. Influence of treatments on characteristics of ruminal and total tract digestion in Holstein steers

\begin{tabular}{|c|c|c|c|c|c|c|c|c|}
\hline \multirow{2}{*}{ Item } & \multicolumn{4}{|c|}{ Treatments $^{1}$} & \multirow{2}{*}{ SEM $^{2}$} & \multirow{2}{*}{ U-4.5 vs OPT- 4.5} & \multicolumn{2}{|c|}{$\mathrm{S}: \mathrm{F}$ ratio } \\
\hline & $\mathrm{U}-4.5$ & OPT-6 & OPT-4.5 & OPT-3 & & & Linear & Quadratic \\
\hline \multicolumn{9}{|l|}{ Intake $(\mathrm{g} / \mathrm{d})$} \\
\hline $\mathrm{DM}^{3}$ & 4,664 & 4,646 & 4,637 & 4,469 & 64 & 0.02 & 0.03 & 0.03 \\
\hline $\mathrm{OM}^{4}$ & 4,403 & 4,419 & 4,387 & 4,370 & 61 & 0.08 & $<0.01$ & 0.31 \\
\hline Starch & 1,903 & 2,239 & 2,084 & 1,761 & 27 & $<0.01$ & $<0.01$ & 0.01 \\
\hline $\mathrm{ADF}^{5}$ & 452 & 374 & 501 & 602 & 7 & $<0.01$ & $<0.01$ & 0.01 \\
\hline $\mathrm{N}^{6}$ & 93 & 100 & 102 & 101 & 1.7 & $<0.02$ & 0.25 & 0.11 \\
\hline $\mathrm{GE}(\mathrm{Mcal} / \mathrm{d})^{7}$ & 21.69 & 21.53 & 21.36 & 21.01 & 0.39 & 0.01 & 0.01 & 0.10 \\
\hline \multicolumn{9}{|l|}{ Ruminal digestion (\%) } \\
\hline $\mathrm{OM}$ & 54.23 & 56.35 & 55.29 & 54.85 & 0.62 & 0.27 & 0.13 & 0.71 \\
\hline Starch & 77.98 & 78.18 & 78.00 & 78.36 & 0.62 & 0.99 & 0.85 & 0.73 \\
\hline $\mathrm{ADF}$ & 26.37 & 19.09 & 26.74 & 27.42 & 1.97 & 0.90 & 0.03 & 0.19 \\
\hline Feed N & 66.22 & 67.02 & 68.38 & 65.50 & 1.10 & 0.15 & 0.29 & 0.12 \\
\hline Duodenal flow of $N(\mathrm{~g} / \mathrm{d})$ & 94.18 & 98.20 & 101 & 98.47 & 2.7 & $<0.01$ & 0.86 & 0.03 \\
\hline Duodenal flow of MN $(\mathrm{g} / \mathrm{d})^{8}$ & 61.06 & 61.58 & 65.70 & 60.60 & 2.01 & $<0.01$ & 0.30 & $<0.01$ \\
\hline MN efficiency ${ }^{9}$ & 25.55 & 24.73 & 27.05 & 25.29 & 0.44 & 0.02 & 0.22 & 0.03 \\
\hline Duodenal flow of NAN $(\mathrm{g} / \mathrm{d})^{10}$ & 92.52 & 94.68 & 97.80 & 95.45 & 0.83 & $<0.01$ & 0.54 & 0.04 \\
\hline $\mathrm{N}$ efficiency ${ }^{11}$ & 0.99 & 0.94 & 0.96 & 0.94 & 0.01 & 0.09 & 0.95 & 0.24 \\
\hline \multicolumn{9}{|c|}{ Postruminal digestion (\% leaving abomasums) } \\
\hline $\mathrm{OM}$ & 65.84 & 64.62 & 63.28 & 60.86 & 1.28 & 0.21 & 0.09 & 0.74 \\
\hline Starch & 94.29 & 94.62 & 94.78 & 94.96 & 0.34 & 0.35 & 0.76 & 0.82 \\
\hline $\mathrm{ADF}$ & 22.47 & 17.96 & 14.33 & 12.68 & 2.40 & 0.07 & 0.17 & 0.75 \\
\hline $\mathrm{N}$ & 75.55 & 76.56 & 77.64 & 76.86 & 4.9 & 0.02 & 0.68 & 0.18 \\
\hline \multicolumn{9}{|l|}{ Total-tract digestion $(\%)$} \\
\hline $\mathrm{DM}$ & 77.65 & 78.89 & 76.81 & 75.10 & 0.57 & 0.28 & $<0.01$ & 0.77 \\
\hline $\mathrm{OM}$ & 78.92 & 80.39 & 78.59 & 76.26 & 0.64 & 0.70 & $<0.01$ & 0.73 \\
\hline Starch & 98.74 & 98.83 & 98.85 & 98.87 & 0.08 & 0.40 & 0.74 & 0.99 \\
\hline $\mathrm{ADF}$ & 42.99 & 33.68 & 37.37 & 36.87 & 0.80 & $<0.01$ & 0.03 & 0.09 \\
\hline $\mathrm{N}$ & 75.28 & 77.08 & 77.75 & 77.48 & 0.64 & $<0.01$ & 0.55 & 0.42 \\
\hline $\mathrm{DE}(\%)^{12}$ & 78.30 & 78.94 & 78.23 & 76.26 & 0.53 & 0.91 & $<0.01$ & 0.33 \\
\hline $\mathrm{DE} \operatorname{diet}(\mathrm{Mcal} / \mathrm{kg})$ & 3.64 & 3.66 & 3.60 & 3.44 & 0.02 & 0.27 & $<0.01$ & 0.10 \\
\hline Observed-to-expected DE & 1.00 & 1.00 & 1.02 & 1.00 & 0.006 & 0.04 & 0.69 & 0.04 \\
\hline
\end{tabular}

${ }^{1} \mathrm{U}-4.5$ = Diet formulated to supply $2.14 \mathrm{Mcal} / \mathrm{kg}$ of $\mathrm{NE}_{\mathrm{m}}$ with a ratio of starch:FDA of 4.5 , containing $0.80 \%$ of conventional urea as the sole source of NNP; OPT-6 = Diet formulated to supply $2.14 \mathrm{Mcal} / \mathrm{kg}$ of $\mathrm{NE}_{\mathrm{m}}$ with a ratio of starch:FDA of 6.0 , containing $0.80 \%$ of conventional urea plus $1.00 \%$ of Optigen; OPT-4.5 = Diet formulated to supply $2.07 \mathrm{Mcal} / \mathrm{kg}$ of $\mathrm{NE}_{\mathrm{m}}$ with a ratio of starch:FDA of 4.5 , containing $0.80 \%$ of conventional urea plus $1.00 \%$ of Optigen, and OPT-3 = Diet formulated to supply $2.00 \mathrm{Mcal} / \mathrm{kg}$ of $\mathrm{NE}_{\mathrm{m}}$ with a ratio of starch:FDA of 3.0 , containing $0.80 \%$ of conventional urea plus $1.00 \%$ of Optigen (OPT-3).

${ }^{2} \mathrm{SEM}=$ Standard error. ${ }^{3} \mathrm{DM}=$ Dry matter. ${ }^{4} \mathrm{OM}=$ Organic matter. ${ }^{5} \mathrm{ADF}=$ Acid detergent fiber. ${ }^{6} \mathrm{~N}=\mathrm{Nitrogen}$.

${ }^{7} \mathrm{GE}=$ Gross energy. ${ }^{8} \mathrm{MN}=$ Microbial nitrogen. ${ }^{9}$ Microbial efficiency is expressed as duodenal $\mathrm{MN}$, $\mathrm{g} / \mathrm{kg} \mathrm{OM}$ fermented in the rumen.

${ }^{10} \mathrm{NAN}=$ Non-ammonia N. ${ }^{11} \mathrm{~N}$ efficiency is expressed as duodenal non-ammonia $\mathrm{N}, \mathrm{g} / \mathrm{g} \mathrm{N}$ intake. ${ }^{12} \mathrm{DE}=\mathrm{Digestible}$ energy.

urea combination increased $(\mathrm{p} \leq 0.02)$ the $\mathrm{MN}$ flow to the duodenum by $7.1 \%$ and the $\mathrm{MN}$ efficiency by $7.3 \%$. Burroughs et al. (1975) proposed that microbial $\mathrm{N}$ flow to the small intestine was equivalent to 0.0166TDN, estimated as follows: $0.0166 \times \mathrm{TDN} \times \mathrm{DMI}, \mathrm{kg} / \mathrm{d}$. According to the expected TDN values (NRC, 1996) and DM intakes of the experimental diets (Table 3), the predicted flow of microbial $\mathrm{N}$ to the small intestine would be $62.3,65.02$, 63.06, and 59.25 g/d with U-4.5, OPT-6, OPT-4.5 and OPT3 , respectively. The MN flows of the U-4.5 and OPT-3 treatments were very close to those expected (98\%); however, surprisingly, the MN flow of treatment OPT-6 was
$5.6 \%$ less than expected. The decreased response observed for OPT-6 can be explained, in part, by the reduced ADF ruminal digestion observed for this $\mathrm{S}: \mathrm{F}$ ratio. In contrast, the urea combination for an S:F ratio of 4.5 produced a flow of $\mathrm{N} 4.2 \%$ greater than expected, reflecting a positive synchrony for this proportion of starch and ADF in the diet. It has been observed that MN production, among others, is a result of synchronization between the rate of hydrolysis of carbohydrates, and the rate at which $\mathrm{N}-\mathrm{NH}_{3}$ is produced during the hydrolysis of $\mathrm{N}$ compounds in the rumen (NRC, 1985; Orskov, 1992). The difference in microbial production observed between U-4.5 and OPT- 4.5 could be 
partially explained by the improved synchrony for the combination of the two urea sources in OPT-4.5.

The S:F ratio did not affect post-ruminal digestion of $\mathrm{OM}$, starch, ADF or N, although the digestion of organic matter tended (linear effect, $\mathrm{p}=0.09$ ) to decrease as the $\mathrm{S}: \mathrm{F}$ ratio in the diet decreased. Irrespective of the proportion of starch and fibre in the diets, the combination of two urea sources improved post-ruminal $\mathrm{N}$ digestion by an average of $2.8 \%(\mathrm{p}=0.02)$ with no difference in the digestion of other components evaluated.

The S:F ratio affected OM and ADF total tract digestion. As the ratio increased, OM digestion increased (linear effect, $\mathrm{p}<0.01)$, but ADF total tract digestion decreased $(\mathrm{p}=0.03)$. The reduction in total tract $\mathrm{OM}$ digestion as the $\mathrm{S}: \mathrm{F}$ ratio decreased was expected, and was largely attributable to relative differences in the total tract digestion of ADF (36\%) versus starch (99\%). Compared to the control diet, the inclusion of OPT in the diets increased the total tract apparent $\mathrm{N}$ digestion $(2.8 \%, \mathrm{p}<0.05)$. However, this effect may be more a function of the increased $\mathrm{N}$ content of the diet brought about by the replacements (Holter and Reid, 1959).

Consistent with the effects on total tract OM digestion, the $S: F$ ratio affected the digestibility of GE. As the ratio decreased, the digestibility of GE also decreased (linear effect, $\mathrm{p}<0.01$ ). According to the expected DE values (NRC, 1996), the predicted DE were 1.00, 1.00, 1.02, and 1.00 times the expected values for U-4.5, OPT-6, OPT-4.5 and OPT-3, respectively. Thus, at a ratio of 4.5 , the digestible energy was improved by $2 \%$ over the expected $(p=0.04)$ level. This improvement represents an increase of 0.077 $\mathrm{Mcal} / \mathrm{kg}$ of digestible energy. If we consider that: i) the contribution of digestible energy content in diets is mainly due to changes in the participation of corn and DDGS; ii) that the DDGS contains a similar energy concentration as corn (Depenbusch et al., 2008; Uwitze et al., 2010); and iii) the difference in the content of DDG plus corn between U4.5 and OPT-4.5 represents $6.5 \%$ (the sum of corn and DDGS participation in U-4.5 is $73 \%$, whereas for diet OPT4.5 it is $66.5 \%$, Table 1), then the $2 \%$ of energy improvement in OPT-4.5 treatment represents the equivalent increase of $4.3 \%[(0.117-0.04) /(0.117 / 6.5)]$ corn grain in the diet.

It is concluded that combining feed grade urea and Optigen resulted in positive effects on the $\mathrm{MN}$ flow and digestible energy of the diet, but apparently these advantages are observed only when there is a certain proportion (4.5) of starch:ADF in the diet. Either a higher or lower S:F ratio than 4.5 failed to offer advantages over any of the parameters evaluated. It is necessary to continue research on the conditions of the finishing diet so that it is possible to get the most out of it with the use of slow release urea.

\section{REFERENCES}

AOAC. 2000. Official methods of analysis, 17th edn. Association of Official Analytical Chemists, Gaithersburg, Maryland.

Bergen, W. G., D. B. Purser, and J. H. Cline. 1968. Effect of ration on the nutritive quality of rumen microbial protein. J. Anim. Sci. 27:1497-1501.

Burroughs, W., D. K. Nelson, and D. R. Mertens. 1975. Protein physiology and its application in the lactating cow: The metabolizable protein feeding standard. J. Anim. Sci. 41:933944.

Depenbusch, B. E., E. R. Loe, M. J. Quinn, M. E. Corrigan, M. L. Gibson, K. K. Karges, and J. S. Drouillard. 2008. Corn distillers grains with solubles derived from a traditional or partial fractionation process: Growth performance and carcass characteristics of finishing feedlot heifers. J. Anim. Sci. 86:2338-2343.

Carrasco, R., A. A. Arrizon, A. Plascencia, N. G. Torrentera, and R. A. Zinn. 2013. Comparative feeding value of distillers dried grains plus solubles as a partial replacement for steam-flaked corn in diets for calf-fed Holstein steers: characteristics of digestion, growth-performance, and dietary energetic. J. Anim. Sci. 91:1801-1810.

FASS. 2010. Guide for the care and use of agricultural animals in agricultural research and teaching, 3rd Ed. Federation of Animal Science Societies. Champaign, IL.

Grant, R. J., and S. J. Weidner. 1992. Digestion kinetics of fiber: Influence of in vitro buffer $\mathrm{pH}$ varied within observed physiological range. J. Dairy Sci. 75:1060-1068.

Haaland, G. L., H. F. Tyrrell, P. W. Moe, and W. E. Wheeler. 1982. Effect of crude protein level and limestone buffer in diets fed at two levels of intake on rumen $\mathrm{pH}$, ammonia-nitrogen, buffering capacity and volatile fatty acid concentration of cattle. J. Anim. Sci. 55:943-950.

Hill, F. N. and D. L. Anderson. 1958. Comparison of metabolizable energy and productive determinations with growing chicks. J. Nutr. 64:587-603.

Holter, J. A. and J. T. Reid. 1959. Relationship between the concentrations of crude protein and apparently digestible protein in forages. J. Anim. Sci. 18:1339-1349.

Huntington, G. B. 1997. Starch utilization by ruminants: from basics to the bunk. J. Anim. Sci. 75:852-867.

Klopfenstein, T. J., G. E. Erickson, and V. R. Bremer. 2008. BOARD-INVITED REVIEW: Use of distillers by-products in the beef cattle feeding industry. J. Anim. Sci. 86:1223-1231.

NRC. 1985. Ruminant nitrogen usage. National Academy Press, Washington, DC.

NRC. 1996. Nutrient requirements of beef cattle. 7th Ed. National Academy of Press, Washington, DC.

Milton, C. T., R. T. Brandt Jr., and E. C. Titgemeyer. 1997. Urea in dry rolled corn diets: Finishing steers performance, nutrient digestion and microbial protein production. J. Anim. Sci. 75: 1415-1424.

Orskov, E. R. 1992. Protein nutrition in ruminants. 2nd Ed. Academic Press, San Diego, CA.

Peters, J. P., R. Y. W. Shen, and J. A. Robinson. 1992. 
Disappearance of acetic acid from the bovine reticulumrumen at based and elevated concentration of acetic acid. J. Anim. Sci. 70:1509-1517.

Rosentrater, K. A. 2012. Feeding DDGS in other animals. In: Distiller grain, production properties and utilization (Ed. K. Lui and K. A. Rosentrater). CRC Press, Boca Raton, Florida. pp. 391-397.

Russell, J. R., A. W. Young, and N. A. Jorgensen. 1980. Effect of sodium bicarbonate and limestone additions to high grain diets on feedlot performance and ruminal and fecal parameters in finishing steers. J. Anim. Sci. 51:996-1002.

Russell, J. B. and D. B. Wilson. 1996. Why are ruminal cellulolytic bacteria unable to digest cellulose at low $\mathrm{pH}$ ? J. Dairy Sci. 79:1503-1509.

Seo, J. K., M. H. Kim, J. Y. Yang, H. J. Kim, C. H. Lee, K. H. Kim, and J. K. Ha. 2013. Effects of synchronicity of carbohydrate and protein degradation on rumen fermentation characteristics and microbial protein synthesis. Asian-Aust. J. Anim. Sci. 26:358-365.

SAS Institute Inc. 2004. SAS/STAT User's Guide: Version 9.1. SAS Institute Inc., Cary, North Caroline.
Uwituze, S., G. L. Parsons, M. K. Shelor, B. E. Depenbusch, K. K. Karges, M. L. Gibson, C. D. Reinhardt, J. J. Higgins, and J. S. Drouillard. 2010. Evaluation of dried distillers grains and roughage source in steam-flaked corn. J. Anim. Sci. 88:258274.

Van Soest, P. J., J. B. Robertson, and B. A. Lewis. 1991. Methods for dietary fiber, neutral detergent fiber, and nonstarch polysaccharides in relation to animal nutrition. J. Dairy. Sci. 74:3583-3597.

Zinn, R. A. 1990. Influence of steaming time on site digestion of flaked corn in steers. J. Anim. Sci. 68:776-781.

Zinn, R. A., R. Barrajas, M. Montaño, and R. A. Ware. 2003. Influence of dietary urea level on digestive function and growth peformance of cattle fed steam-flaked barley- based finishing diets. J. Anim. Sci. 81:2383-2389.

Zinn, R. A. and F. N. Owens. 1986. A rapid procedure for purine measurement and its use for estimating net ruminal protein synthesis. Can. J. Anim. Sci. 66:157-166.

Zinn, R. A. and F. N. Owens. 1983. Site of protein digestion in steers: Predictability. J. Anim. Sci. 56:707-716.

Zinn, R. A. and A. Plascencia. 1993. Interaction of whole cottonseed and supplemental fat on digestive function in cattle. J. Anim. Sci. 71:11-17. 